\title{
Sustainable Solutions to Wastewater Management: Maximizing the Impact of Territorial Co-operation
}

\author{
Georgios Sylaios $^{1} \cdot$ Georgios Gikas $^{1}$. \\ Vassilios A. Tsihrintzis ${ }^{2}$
}

(C) Springer International Publishing Switzerland 2016

This issue of Environmental Processes presents a collection of 7 papers initially presented at the WASTEnet Program International Conference "Sustainable Solutions to Wastewater Management: Maximizing the Impact of Territorial Co-operation". The conference was held from June 19-21, 2015, in Kavala, East Macedonia, Greece (http://wastenet2015.org/). The conference was the final event of the WASTEnet Program funded by the Joint Managing Authority for the Joint Operational Program "Black Sea Basin 2007-2013".

The scope of the international conference was to explore the potentials of low cost and energy solutions to wastewater management, and to present through the activities carried out by the WASTEnet partnership the state-of-the-art in the field of Sustainable Wastewater Treatment Systems, with emphasis on Natural Treatment Systems, Constructed Wetlands and other small or on-site treatment systems. The ultimate aim was the implementation potential of such wastewater treatment systems in the wider Black Sea Basin area, and generally, in developing countries. The conference also emphasized on the diffusion of the best available knowledge in this field from international experts and the exchange of experiences with an audience composed of key decision makers from the local, the regional and the national level, the EU representation in these Black Sea countries, NGOs, professional

Vassilios A. Tsihrintzis

tsihrin@otenet.gr; tsihrin@survey.ntua.gr; tsihrin@central.ntua.gr

Georgios Sylaios

gsylaios@env.duth.gr

Georgios Gikas

ggkikas@env.duth.gr

1 Laboratory of Ecological Engineering \& Technology, Department of Environmental Engineering, School of Engineering, Democritus University of Thrace, 67100 Xanthi, Greece

2 Centre for the Assessment of Natural Hazards and Proactive Planning \& Laboratory of Reclamation Works and Water Resources Management, School of Rural and Surveying Engineering, National Technical University of Athens, 9 Iroon Polytechniou St., Zografou 15780 Athens, Greece 
associations, the private sector and other major actors, which decisively contributed to starting a process that will lead to tangible results for local communities and foster broader and deeper transnational cooperation in the wider Black Sea Basin region. The conference also helped local and regional authorities and stakeholders to gain insight on the role of innovative and environmentally-friendly technologies, in improving the environment in remote, rural communities of the broader Black Sea region.

A total number of 56 papers and 12 posters were presented at the conference, which was organized under the auspices of the European Water Resources Association (EWRA). Thus, some papers were selected for inclusion in three EWRA journals, Environmental Processes, European Water and Water Utility Journal.

This special issue of Environmental Processes was guest-edited by professors: Georgios Sylaios (Democritus University of Thrace, Xanthi, Greece), Georgios Gikas (Democritus University of Thrace, Xanthi, Greece), and Vassilios A. Tsihrintzis (National Technical University of Athens, Athens, Greece). The papers included in this special issue are based on the initial presentations at the conference. However, they have been extended and revised having passed through the regular reviewing process of the journal. The topics dealt in the seven papers are briefly presented below:

Kalaitzidou et al. (2016), aiming to achieve phosphate recovery from secondary effluents of an urban biological wastewater treatment plant, investigated the adsorption onto single iron (GFH, Bayoxide and $\mathrm{FeOOH}$ ) and onto binary iron-manganese (AquAsZero) oxy-hydroxides, as well as the ion exchange by using Purolite A200EMBCL resin. Laboratory batch experiments and dynamic Rapid Small Scale Column Tests were conducted. Based on the results, AquAsZero was further implemented in a pilot-plant specifically constructed and operated. The results indicate that phosphate adsorption onto iron-based adsorbents is a promising technology resulting in nearly zero residual phosphate concentrations.

Melidis et al. (2016) investigated the operation of a submerged hollow fibre membrane bioreactor treating municipal wastewater under different organic loading rates and high mixed liquor suspended solids concentrations. The system achieved complete suspended solids removal, and BOD, COD, TKN and $\mathrm{NH}_{4}{ }^{+}-\mathrm{N}$ mean removal rates of more than 97, 93, 77 and $91 \%$, respectively. The system could also effectively operate without membrane fouling for a long period of time, even at high volumetric organic loading rates and high biosolids concentrations.

Aravantinou et al. (2016) investigated the use of Chlorococcum sp. in nutrient removal from wastewater, and the evaluation of algal biomass growth and lipid production. The experiments were conducted under controlled conditions using a 30-L open tank fed with primarily and secondarily treated wastewater from an activated sludge treatment plant. Nitrate removal, with the secondary effluent, was up to $98 \%$, and the lower removal efficiencies were observed at low HRTs. The higher lipid content of Chlorococcum sp. was observed when the pond was fed with the secondary effluent.

Liolios et al. (2016) evaluated numerically the effects of two alternative operational techniques, i.e., effluent recirculation and step-feeding, on the removal of BOD in horizontal subsurface flow constructed wetlands (HSF CWs). The Visual MODFLOW family code was used which has been calibrated using experimental data collected in five HSF CW pilot-scale units. Effluent recirculation was not found to improve the performance of constructed wetlands, with lower treatment efficiencies seen with increased effluent recirculating quantity. Similarly, step-feeding showed no performance improvement for all tested cases. Thus, both operation modes are not recommended for HSF CWs. 
Kotti et al. (2016) developed and applied a fuzzy logic model to predict nitrogen and phosphorus removal efficiency in free-water surface (FWS) constructed wetlands (CWs). For this, they used nitrogen and phosphorus removal data, collected within a 2-year period in five pilot FWS CW units. Model predictions showed fairly good agreement with experimental data, as well as with independent data from various other CWs of different settings and operating conditions, proposing the presented methodology as a satisfactory modeling tool.

Diamantis et al. (2016) developed a technology for producing biogas from organic waste by-products from agro-industrial enterprises utilizing geothermal energy for bioreactor heating. Wastes included by-products from a cheese manufacturing plant, an olive mill and a cattle breeding facility. The experiments took place in an $8 \mathrm{~m}^{3}$ specifically-designed and constructed geothermal anaerobic digester. The higher biogas yield was obtained from cheese whey, followed by olive mill and by cattle wastewater. The technology can recover $100 \%$ more biogas for added-value applications, utilizing organic wastes and low enthalpy geothermal fluids.

Gaidajis and Angelakoglou (2016) proposed twelve key indicators utilized for the evaluation of sustainable water consumption and management of industrial facilities. These indicators were further assessed based on five predefined criteria, and a five-point grading system was applied to rank them. The methodology can help industries to significantly improve the way they assess water related performance following a sustainability-oriented approach.

\section{References}

Aravantinou AF, Frementinti A, Manariotis ID (2016) Post treatment of primary and secondary effluent by Chlorococcum sp. Environ Process. doi:10.1007/s40710-016-0153-3

Diamantis V, Tataki V, Eftaxias A, Iliadis G, Aivasidis A (2016) Geothermal energy valorisation for enhanced biogas production from agro-industrial residues. Environ Process. doi:10.1007/s40710-016-0182-y

Gaidajis G, Angelakoglou K (2016) Sustainability of industrial facilities through water indicators. Environ Process. doi:10.1007/s40710-016-0158-y

Kalaitzidou K, Mitrakas M, Raptopoulou C, Tolkou A, Palasantza P-A, Zouboulis A (2016) Pilot-scale phosphate recovery from secondary wastewater effluents. Environ Process. doi:10.1007/s40710-016-0139-1

Kotti IP, Sylaios GK, Tsihrintzis VA (2016) Fuzzy modeling for nitrogen and phosphorus removal estimation in free-water surface constructed wetlands. Environ Process. doi:10.1007/s40710-016-0177-8

Liolios KA, Moutsopoulos KN, Tsihrintzis VA (2016) Modelling alternative feeding techniques in HSF constructed wetlands. Environ Process. doi:10.1007/s40710-016-0175-X

Melidis P, Ntougias S, Vasilatou V, Skouteris G, Azis K, Diamantis V, Alexandridis A (2016) Biofouling aspects and critical flux evaluation in an intermittently aerated and fed submerged membrane bioreactor. Environ Process. doi:10.1007/s40710-016-0159-x 